\title{
The Rise of Labour and the Fall of Empire
}

\author{
The Memoirs of William Hare, Fifth Earl of Listowel
}

The life and career of William Francis Hare (1906-1997), fifth Earl of Listowel, witnessed some of the most remarkable events in twentieth-century British history. Joining a small band of Labour supporters in the House of Lords in 1932 and later holding senior ministerial posts under Attlee, he was at the forefront of Labour politics for over sixty years. At the time of his death in 1997, he was the longest serving member of both the House of Lords and the Privy Council. Educated at Eton and Oxford and Cambridge, 'Billy' Listowel, born into an aristocratic Anglo-Irish family, was from an early age devoted to social democracy and to eradicating injustice in Britain and the world. During the interwar years he witnessed the fall of Republican Spain and campaigned on behalf of China. He served in the intelligence corps, and eventually took office in the wartime coalition. Entering the Attlee Cabinet in 1945 while still in his thirties, he became the last Secretary of State for India and Burma and thus took a critical role in the climactic end of Britain's Indian Empire and the subsequent emergence of the modern states of India, Pakistan and Burma. Further roles awaited him, including official work in Australasia, the Caribbean, and Africa, and being Kwame Nkrumah's choice to be the last Governor General of Ghana. Listowel remained active in the Lords and in Labour politics well into the 1980s. The Rise of Labour and the Fall of Empire gives a privileged account of British History in the twentieth century and especially of the decolonization of the British Empire.

DR H. KUMARASINGHAM is Senior Lecturer in British Politics at the University of Edinburgh. He is a political historian of Britain, the British Empire and the Commonwealth. His recent work covers the decolonization of the British Empire and subsequent state-building that followed. He is the author of many works, including A Political Legacy of the British Empire: Power and the Parliamentary System in Post-Colonial India and Sri Lanka (London 2013) and Constitution-Maker: Selected Writings of Sir Ivor Jennings, Royal Historical Society, Camden 5th ser. (Cambridge, 2015). He is currently writing, for Cambridge University Press, a history of the Crown's legacy in South Asia and co-editing The Cambridge Constitutional History of the United Kingdom. He is a Fellow of the Royal Historical Society.

Cover photo: Indian philosopher, statesman, and nationalist leader Mahatma Gandhi, with Lord Listowel, Secretary of State for Burma, at Government House, New Delhi, 16 September 1947. (Photo by Keystone/Getty Images)

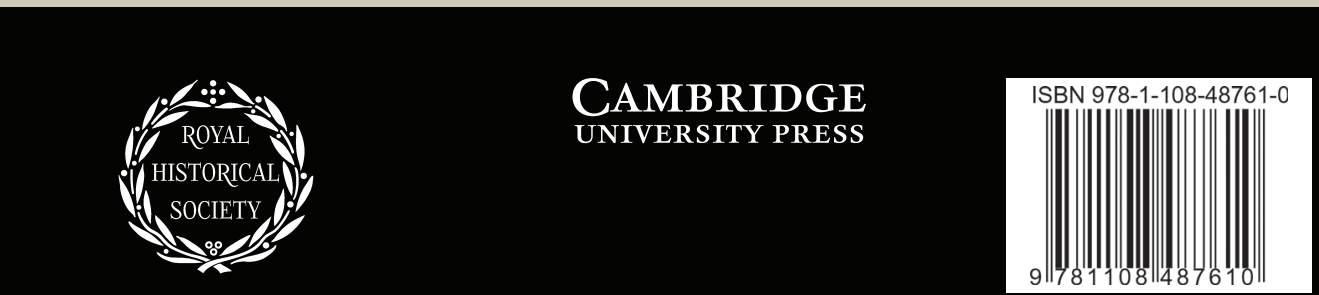

